CRYSTALLOGRAPHIC COMMUNICATIONS

ISSN 2056-9890

Received 7 February 2018

Accepted 10 February 2018

Edited by W. T. A. Harrison, University of Aberdeen, Scotland

‡ Additional correspondence author, e-mail: edwardt@sunway.edu.my.

Keywords: crystal structure; dihydropyrrole; ester; nitro-O $\cdots \pi$ interactions; Hirshfeld surface analysis.

CCDC reference: 1823263

Supporting information: this article has supporting information at journals.iucr.org/e

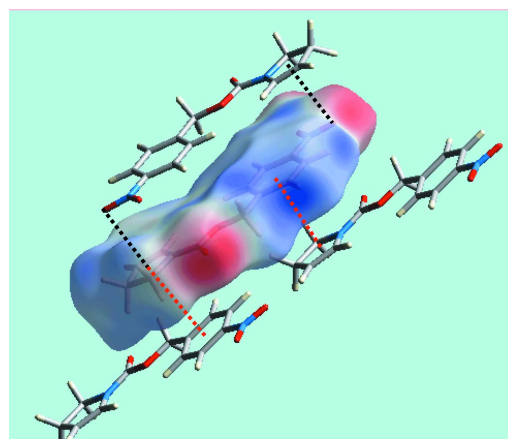

OPEN $\odot$ ACCESS

\section{(4-Nitrophenyl)methyl 2,3-dihydro-1H-pyrrole-1- carboxylate: crystal structure and Hirshfeld analysis}

\author{
Julio Zukerman-Schpector, ${ }^{a *}$ Monica Soto-Monsalve, ${ }^{\mathrm{b}}$ Regina H. De Almeida \\ Santos, ${ }^{\text {b }}$ Ariel L. L. Garcia, ${ }^{c}$ Carlos Roque D. Correia, ${ }^{\mathrm{c}}$ Mukesh M. Jotani ${ }^{\mathrm{d}}$ and \\ Edward R. T. Tiekink ${ }^{\mathrm{e}}$
}

\begin{abstract}
'Laboratório de Cristalografia, Esterodinâmica e Modelagem Molecular, Departamento de Química, Universidade Federal de São Carlos, 13565-905 São Carlos, SP, Brazil, 'b Instituto de Química de São Carlos, Universidade de São Paulo, São Carlos, SP, Brazil, 'Instituto de Química, Universidade Estadual de Campinas, UNICAMP, CP 6154, CEP. 13084-971, Campinas, São Paulo, Brazil, 'Department of Physics, Bhavan's Sheth R. A. College of Science, Ahmedabad, Gujarat 380 001, India, and ${ }^{\mathbf{e} C e n t r e}$ for Crystalline Materials, School of Science and Technology, Sunway University, 47500 Bandar Sunway, Selangor Darul Ehsan, Malaysia. *Correspondence e-mail: julio@power.ufscar.br
\end{abstract}

In the title compound, $\mathrm{C}_{12} \mathrm{H}_{12} \mathrm{~N}_{2} \mathrm{O}_{4}$, the dihydropyrrole ring is almost planar (r.m.s. deviation $=0.0049 \AA$ ) and is nearly coplanar with the adjacent $\mathrm{C}_{2} \mathrm{O}_{2}$ residue [dihedral angle $=4.56(9)^{\circ}$ ], which links to the 4-nitrobenzene substituent [dihedral angle $=4.58(8)^{\circ}$ ]. The molecule is concave, with the outer rings lying to the same side of the central $\mathrm{C}_{2} \mathrm{O}_{2}$ residue and being inclined to each other [dihedral angle $\left.=8.30(7)^{\circ}\right]$. In the crystal, supramolecular layers parallel to $(10 \overline{5})$ are sustained by nitrobenzene- $\mathrm{C}-\mathrm{H} \cdots \mathrm{O}$ (carbonyl) and pyrrole-C $-\mathrm{H} \cdots \mathrm{O}$ (nitro) interactions. The layers are connected into a threedimensional architecture by $\pi$ (pyrrole) $-\pi$ (nitrobenzene) stacking [intercentroid separation $=3.7414(10) \AA]$ and nitro- $\mathrm{O} \cdots \pi($ pyrrole $)$ interactions.

\section{Chemical context}

Many hydroxylated prolines and homoprolines have the ability to inhibit glycosides and glycosyltransferases, key enzymes in biosynthesis and the processing of glycoproteins and glycolipids (Rule et al., 1985; Fleet \& Son, 1988; Wong, 1997). Glycoproteins are macromolecules involved in the recognition (cell-cell interactions and host-pathogen) and control of mechanisms associated with biological structures. Thus, compounds that are capable of inhibiting the biosynthetic pathway of glycoproteins have broad chemotherapeutic potential in the treatment of metabolic diseases such as diabetes, obesity, cancer, tuberculosis and viral infections among others (Kordik \& Reitz, 1999; Nishimura, 2003; Cheng \& Josse, 2004). Some hydroxylated prolines are of interest in this context owing to their ability to inhibit glycosidases and because they are found as substructures of natural bioactive compounds. For example, $(2 S, 3 R, 4 S)$-3,4-dihydroxyproline (II), see scheme, is found as a component of the repeating decapeptide sequence of the Mefp1 adhesive protein (Mytilus edulis foot protein 1), produced by the marine mussel, Mytilus edulis (Taylor et al., 1994; Taylor \& Weir, 2000). This protein is responsible for the fixation of mussels to rocks. As a part of a study into the development of new and flexible methodologies for the efficient synthesis of several natural and synthetic products with important pharmacological properties, using the Heck-Matsuda arylation reaction as a crucial step, (II) was prepared from the title compound, (I), for the purpose of 
evaluating the best protecting group for use in future syntheses of greater complexity (Garcia, 2008). During the HeckMatsuda reaction, it was found that the protective group of the nitrogen atom in (I) exerted some influence on the reaction time, but did not influence the yield of the expected intermediate when compared to the Heck-Matsuda reaction applied to the enecarbamate, ethyl 2,3-dihydro- $1 H$-pyrrole-1carboxylate (Garcia, 2008). It is noted that the first synthesis of (I) was actually reported nearly 50 years ago (Heine \& Mente, 1971). Herein, the crystal and molecular structures of (I) are described along with an analysis of the calculated Hirshfeld surfaces.<smiles>O=C(OCc1ccc([N+](=O)[O-])cc1)N1C=CCC1</smiles><smiles>O=C(O)[C@H]1NC[C@@H](O)[C@@H]1O</smiles>

\section{Structural commentary}

The molecular structure of (I), Fig. 1, is a 1-methylene-4nitrobenzene ester derived from dihydropyrrole-1-carboxylic acid. In (I), the dihydropyrrole ring is almost planar with the r.m.s. deviation of the five fitted atoms being $0.0049 \AA$, and the maximum deviation of any of the constituent atoms being 0.0065 (11) $\AA$ for atom $\mathrm{C} 2$. The adjacent $\mathrm{C}_{2} \mathrm{O}_{2}$ residue $(\mathrm{O} 1, \mathrm{O} 2, \mathrm{C} 5, \mathrm{C} 6)$ is essentially co-planar, with the dihedral angle between the two planes being $4.56(9)^{\circ}$. The planarity extends

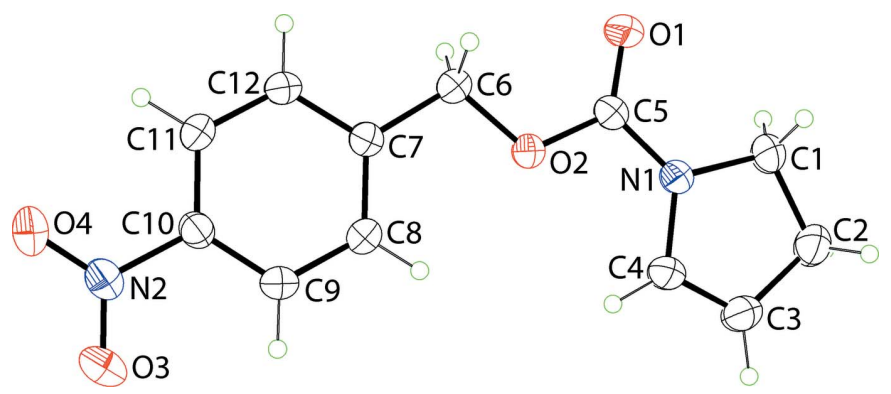

Figure 1

The molecular structure of (I), showing the atom-labelling scheme and displacement ellipsoids at the $35 \%$ probability level.
Table 1

Hydrogen-bond geometry $\left(\AA \stackrel{\circ}{\circ}^{\circ}\right)$.

$C g 1$ is the centroid of the $\mathrm{N} 1 / \mathrm{C} 1-\mathrm{C} 4$ ring.

\begin{tabular}{lllll}
\hline$D-\mathrm{H} \cdots A$ & $D-\mathrm{H}$ & $\mathrm{H} \cdots A$ & $D \cdots A$ & $D-\mathrm{H} \cdots A$ \\
\hline $\mathrm{C} 4-\mathrm{H} 4 \cdots \mathrm{O} 3^{\mathrm{i}}$ & 0.93 & 2.40 & $3.227(2)$ & 149 \\
$\mathrm{C} 12-\mathrm{H} 12 \cdots \mathrm{O} 1^{\mathrm{ii}}$ & 0.93 & 2.47 & $3.318(2)$ & 152 \\
$\mathrm{~N} 2-\mathrm{O} 4 \cdots C g 1^{\mathrm{iii}}$ & $1.22(1)$ & $3.42(1)$ & $3.6327(16)$ & $90(1)$ \\
\hline
\end{tabular}

Symmetry codes: (i) $\quad-x+\frac{1}{2}, y-\frac{1}{2},-z+\frac{1}{2} ; \quad$ (ii) $\quad-x+2,-y+1,-z+1$; (iii) $-x+1,-y+1,-z+1$.

to the 4-nitrobenzene ring, with the dihedral angle between the $\mathrm{C}_{2} \mathrm{O}_{2}$ and $\mathrm{C}_{6}$ planes being $4.58(8)^{\circ}$. However, the molecule is not planar but rather is curved as the outer rings lie to the same side of the central $\mathrm{C}_{2} \mathrm{O}_{2}$ residue; the dihedral angle = $8.30(7)^{\circ}$. To a first approximation, the nitro group is co-planar

(a)

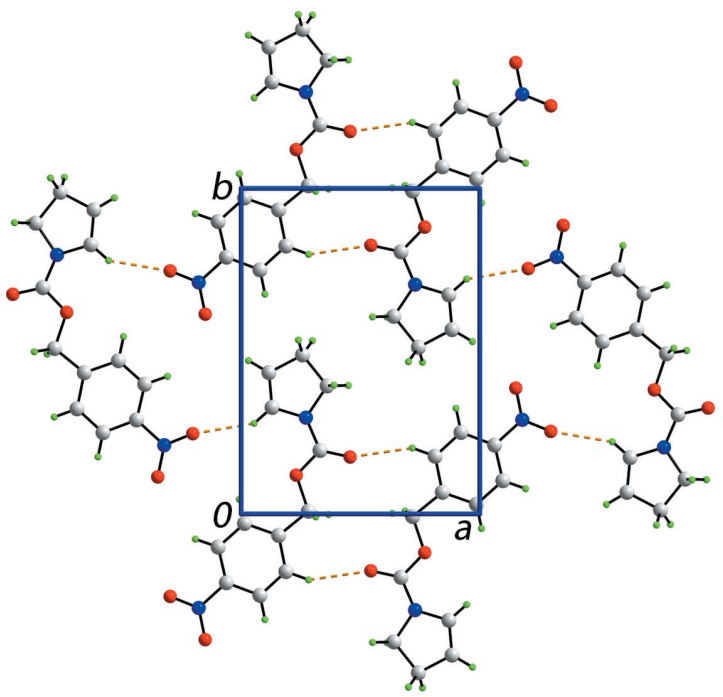

(b)

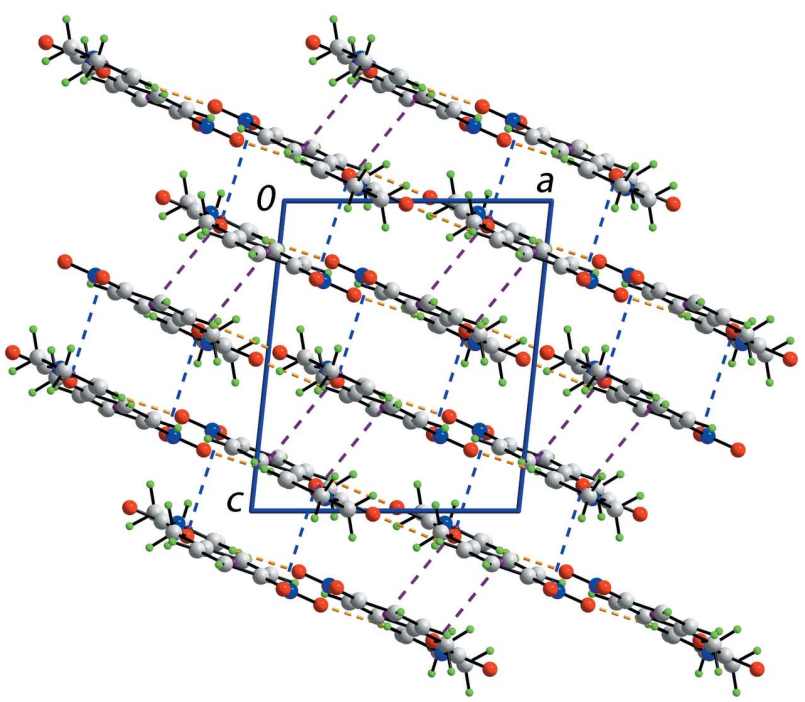

Figure 2

Molecular packing in (I): (a) view of the supramolecular layer parallel to $(10 \overline{5})$ plane and $(b)$ view of the unit-cell contents shown in projection down the $b$ axis. The $\mathrm{C}-\mathrm{H} \cdots \mathrm{O}, \mathrm{N}-\mathrm{O} \cdots \pi$ and $\pi-\pi$ contacts are shown as orange, blue and purple dashed lines, respectively. 
with the benzene ring to which is connected, as seen in the value of the $\mathrm{O} 4-\mathrm{N} 2-\mathrm{C} 10-\mathrm{C} 9$ torsion angle of $173.50(15)^{\circ}$.

\section{Supramolecular features}

The molecular packing of (I) features a variety of directional interactions, Table 1 . Thus, nitrobenzene-C12$\mathrm{H}$... O1(carbonyl) interactions occur over a centre of inversion and lead to $14-$ membered $\left\{\cdots \mathrm{HC}_{3} \mathrm{OCO}\right\}_{2}$ synthons. The dimeric aggregates are connected into a supramolecular layer via pyrrole- $\mathrm{C} 4-\mathrm{H} \cdots \mathrm{O} 3$ (nitro) interactions. The layers lie parallel to $(10 \overline{5})$, Fig. $2 a$. Two types of interactions connect layers into a three-dimensional architecture.Thus, $\pi(\mathrm{N} 1, \mathrm{C} 1-$ $\mathrm{C} 4)-\pi(\mathrm{C} 7-\mathrm{C} 12)^{\mathrm{i}}$ stacking interactions occur between pyrrole and nitrobenzene rings: inter-centroid separation = $3.7414(10) \AA$ and angle of inclination $=7.99(9)^{\circ}$ for symmetry code: (i): $\frac{3}{2}-x,-\frac{1}{2}+y, \frac{1}{2}-z$. The other interactions between layers are of the type nitro-O4 $\cdots \pi(\mathrm{N} 1, \mathrm{C} 1-\mathrm{C} 4)$,

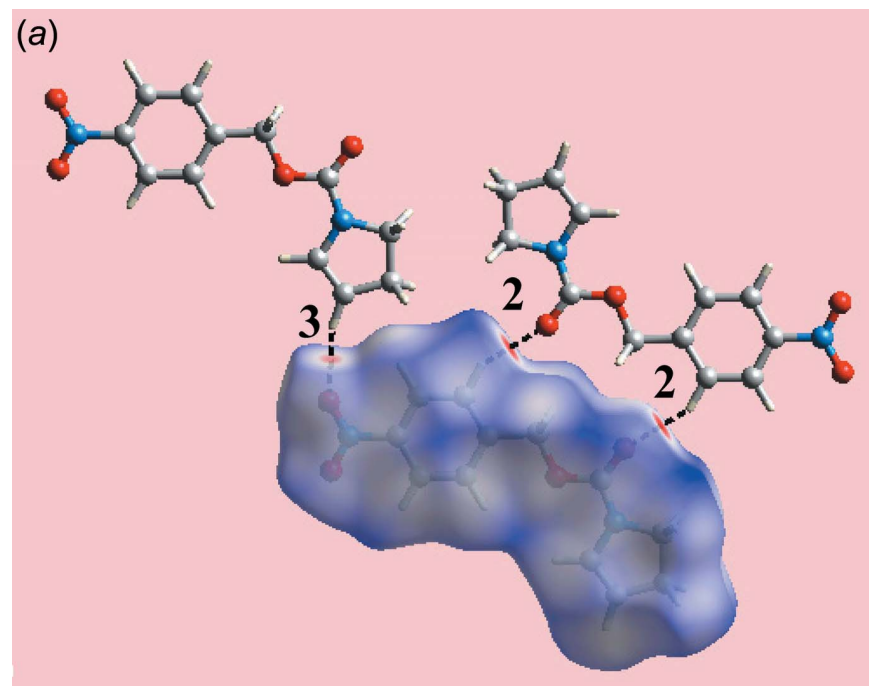

(b)

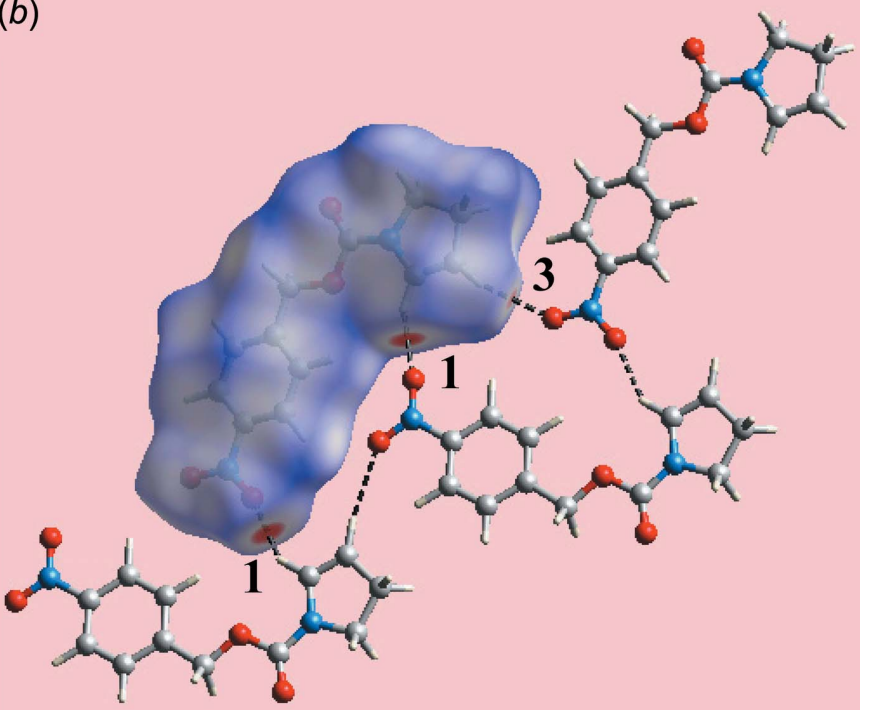

Figure 3

Two views of the Hirshfeld surface for (I) mapped over $d_{\text {norm }}$ in the range -0.225 to $+1.393 \mathrm{au}$, showing intermolecular $\mathrm{C}-\mathrm{H} \cdots \mathrm{O}$ contacts as black dashed lines.
Table 1. These interactions are well known in consolidating the packing of nitro-containing compounds (Huang et al., 2008). A view of the unit-cell contents is shown in Fig. $2 b$.

\section{Hirshfeld surface analysis}

The Hirshfeld surface calculations for (I) were performed as per a recent study (Zukerman-Schpector et al., 2017) and serve to provide additional information on the molecular packing.

In addition to the bright-red spots on the Hirshfeld surface mapped over $d_{\text {norm }}$ in Fig. 3 near the pyrrole-H4, nitrobenzene-H12, and the nitro-O3 and carbonyl-O1 atoms,

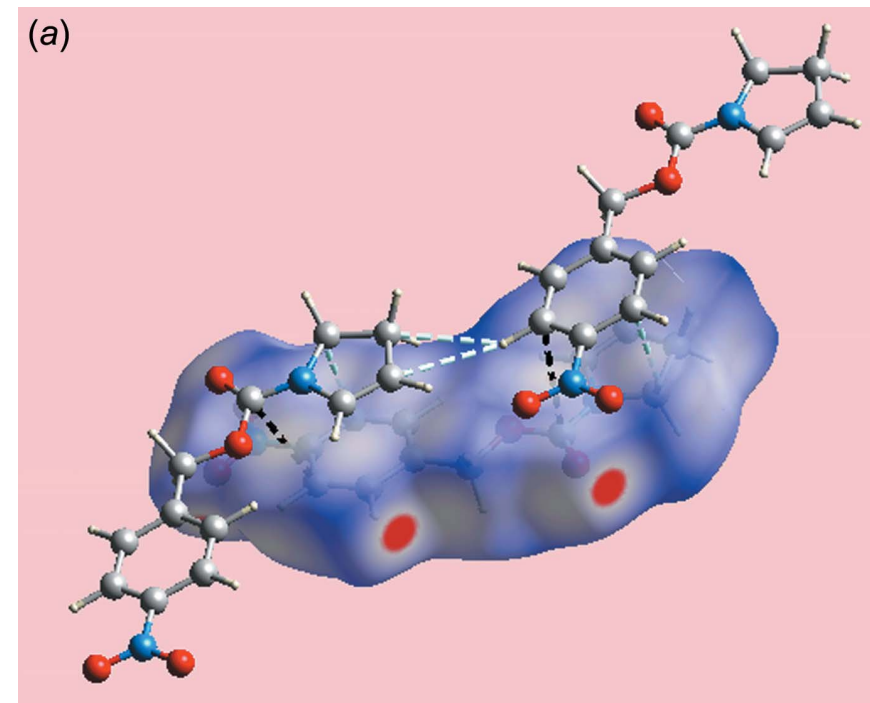

(b)

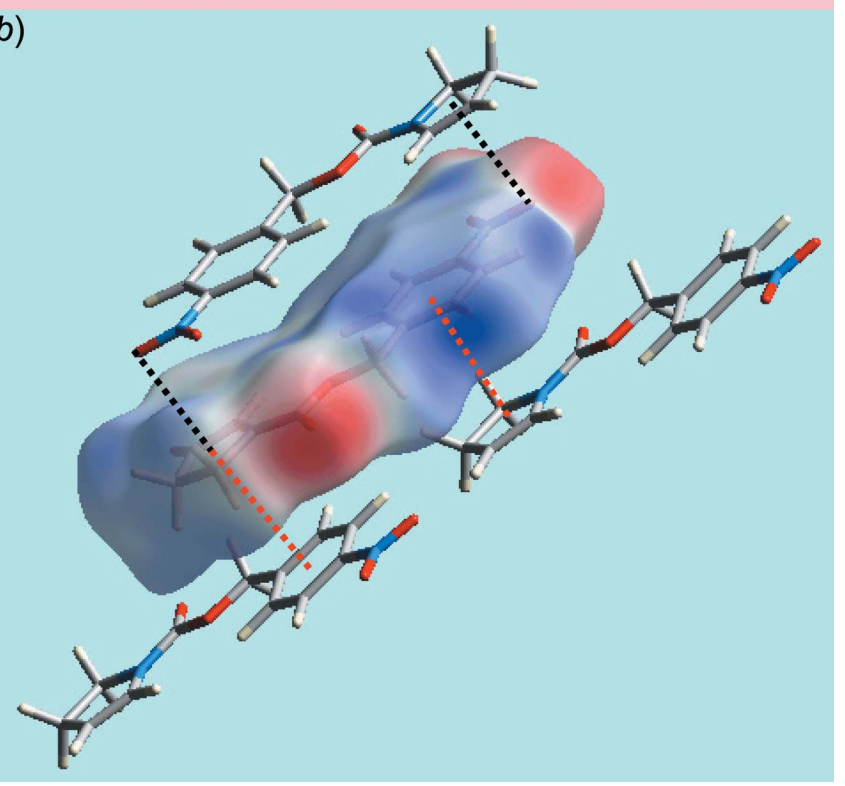

Figure 4

Views of Hirshfeld surfaces for (I) mapped: (a) over $d_{\text {norm }}$ in the range -0.225 to +1.393 au, highlighting inter- and intra-layer $\mathrm{C} \cdots \mathrm{C}$ and $\mathrm{C} \cdots \mathrm{H} /$ $\mathrm{H} \cdots \mathrm{C}$ contacts as black and sky-blue dashed lines, respectively, and (b) over the electrostatic potential in the range \pm 0.077 au (the red and blue regions represent negative and positive electrostatic potentials, respectively), showing intermolecular $\mathrm{N}-\mathrm{O} \cdots \pi$ and $\pi-\pi$ contacts as black dotted lines. 
Table 2

Summary of short interatomic contacts $(\AA)$ in (I).

\begin{tabular}{|c|c|c|}
\hline Contact & Distance & Symmetry operation \\
\hline $\mathrm{O} 4 \cdots \mathrm{H} 3$ & 2.47 & $x,-1+y, z$ \\
\hline $\mathrm{C} 5 \cdots \mathrm{C} 11$ & 3.37 & $\frac{3}{2}-x,-\frac{1}{2}+y, \frac{1}{2}-z$ \\
\hline 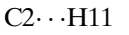 & 2.81 & $x,-1+y, z$ \\
\hline 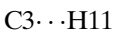 & 2.91 & $x,-1+y, z$ \\
\hline $\mathrm{C} 9 \cdots \mathrm{H} 1 B$ & 2.92 & $\frac{3}{2}-x, \frac{1}{2}+y, \frac{1}{2}-z$ \\
\hline
\end{tabular}

representing the respective donors and acceptors of intermolecular $\mathrm{C}-\mathrm{H} \cdots \mathrm{O}$ interactions (labelled ' 1 ' and ' 2 '), the diminutive red spots appearing near the pyrrole-H3 and nitroO4 atoms in Fig. 3 (labelled ' 3 ') also indicate the influence of comparatively weak $\mathrm{C}-\mathrm{H}$...O contacts in the crystal (Table 2). The nitrobenzene-C9 and $\mathrm{C} 11$ atoms form interlayer short $\mathrm{C} \cdots \mathrm{H} / \mathrm{H} \cdots \mathrm{C}$ and $\mathrm{C} \cdot \mathrm{C}$ contacts (Table 2) with the pyrrole-H $1 B$ and ester-C5 atoms, respectively, Fig. $4 a$. The other short interatomic $\mathrm{C} \cdot \mathrm{H} / \mathrm{H} \cdot \mathrm{C}$ C contacts between the nitrobenzene-H11 and pyrrole-C2 and $\mathrm{C} 3$ atoms (Table 2) are intra-layer, Fig. $4 a$. The building up of the three-dimensional architecture through $\pi-\pi$-stacking interactions and nitro- $\mathrm{N}-$ $\mathrm{O} \cdots \pi$ (pyrrole) contacts is highlighted in Fig. $4 b$, showing the Hirshfeld surface mapped over the electrostatic potential.

The overall two-dimensional fingerprint plot and those delineated into $\mathrm{H} \cdots \mathrm{H}, \mathrm{O} \cdots \mathrm{H} / \mathrm{H} \cdots \mathrm{O}$ and $\mathrm{C} \cdots \mathrm{H} / \mathrm{H} \cdots \mathrm{C}$ contacts (McKinnon et al., 2007) are illustrated in Fig. $5 a-d$, respectively, and the percentage contribution from the identified interatomic contacts to the Hirshfeld surface are summarized in Table 3. The comparatively low, i.e. 39.0\%, contribution from $\mathrm{H} \cdot \cdots \mathrm{H}$ contacts to the overall surface is due to the involvement of many hydrogen atoms in directional intermolecular interactions, e.g. $\mathrm{C}-\mathrm{H} \cdots \mathrm{O}, \pi$ (Tables 1 and 2). Hence, the interatomic $\mathrm{H} \cdot \mathrm{H}$ contacts have a reduced influence in the crystal as their interatomic separations are equal to or greater than sum of their van der Waals radii (Fig. $5 b$ ). Conversely, the relatively significant contribution of $33.8 \%$ from $\mathrm{O} \cdots \mathrm{H} / \mathrm{H} \cdots \mathrm{O}$ contacts to the Hirshfeld surface is consistent with this observation. The fingerprint plot delineated into $\mathrm{O} \cdots \mathrm{H} / \mathrm{H} \cdots \mathrm{O}$ contacts (Fig. $5 c$ ) features a pair of green aligned points within the pair of spikes with their tips at $d_{\mathrm{e}}+d_{\mathrm{i}} \sim 2.3 \AA$ superimposed upon a distribution blue points characterizing intermolecular $\mathrm{C}-\mathrm{H} \cdots \mathrm{O}$ interactions. The short interatomic C $\cdots \mathrm{H} / \mathrm{H} \cdots \mathrm{C}$ contacts in the inter- and intra-
Table 3

Percentage contributions of interatomic contacts to the Hirshfeld surface for (I).

\begin{tabular}{ll}
\hline Contact & Percentage contribution \\
\hline $\mathrm{H} \cdots \mathrm{H}$ & 39.0 \\
$\mathrm{O} \cdots \mathrm{H} / \mathrm{H} \cdots \mathrm{O}$ & 33.8 \\
$\mathrm{C} \cdots \mathrm{H} / \mathrm{H} \cdots \mathrm{C}$ & 15.2 \\
$\mathrm{C} \cdots \mathrm{O} / \mathrm{O} \cdots \mathrm{C}$ & 3.7 \\
$\mathrm{C} \cdots \mathrm{C}$ & 2.4 \\
$\mathrm{C} \cdots \mathrm{N} / \mathrm{N} \cdots \mathrm{C}$ & 1.7 \\
$\mathrm{O} \cdots \mathrm{O}$ & 1.4 \\
$\mathrm{~N} \cdots \mathrm{H} / \mathrm{H} \cdots \mathrm{N}$ & 1.0 \\
$\mathrm{~N} \cdots \mathrm{O} / \mathrm{O} \cdots \mathrm{N}$ & 0.9 \\
$\mathrm{~N} \cdots \mathrm{N}$ & 0.9 \\
\hline
\end{tabular}

layer regions are represented by the two pairs of short forcepslike spikes at $d_{\mathrm{e}}+d_{\mathrm{i}} \sim 2.8$ and $2.9 \AA$, respectively, in Fig. $5 d$. The small but discernible contributions from interatomic C . C C and C . . N/N . . C contacts (Table 3) result from short inter-layer contacts and $\pi-\pi$ stacking interactions. The presence of the $\mathrm{N}-\mathrm{O} \cdots \pi$ contact in the structure is also evident from the contribution of $\mathrm{C} \cdot \mathrm{O} / \mathrm{O} \cdots \mathrm{C}$ and $\mathrm{N} \cdots \mathrm{O} /$ $\mathrm{O} \cdots \mathrm{N}$ contacts to the Hirshfeld surface as summarized in Table 3. The small contributions from the other remaining interatomic contacts (Table 3 ) have a negligible influence on the packing.

\section{Database survey}

Dihydropyrrole rings as found in (I) have rarely been characterized crystallographically and only one structure is deposited in the Cambridge Structural Database (Groom et al., 2016), namely the adduct, $\mathrm{ZnI}_{2}$ (4,5-dihydro-3H-pyrrole $)_{2}$ (refcode WAZXAW; Freer et al., 1993). Here, despite having $s p^{2}$-carbon centres as in (I), the rings are planar with one lying on a crystallographic mirror plane and the other disposed across a mirror plane (r.m.s. deviation $=0.007 \AA$ ), implying disorder in the latter.

\section{Synthesis and crystallization}

A solution of (4-nitrophenyl)methyl 2-hydroxypyrrolidine-1carboxylate $(2.85 \mathrm{~g}, 10.704 \mathrm{mmol})$ in toluene $(100 \mathrm{ml})$ was cooled to $273 \mathrm{~K}$ in an ice/water bath. Under an atmosphere of
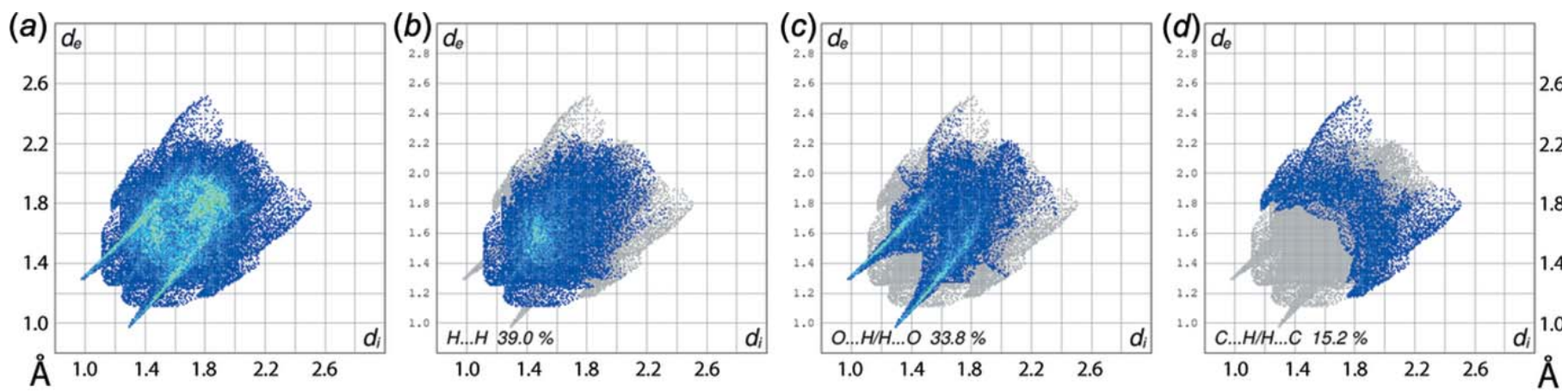

Figure 5

(a) The full two-dimensional fingerprint plot for (I) and those delineated into $(b) \mathrm{H} \cdots \mathrm{H},(c) \mathrm{O} \cdots \mathrm{H} / \mathrm{H} \cdots \mathrm{O}$ and $(d) \mathrm{C} \cdots \mathrm{H} / \mathrm{H} \cdots \mathrm{C}$ contacts. 
nitrogen, 2,4-lutidine $(6.2 \mathrm{ml}, 53.634 \mathrm{mmol})$ was added to this solution. The solution was stirred for $15 \mathrm{~min}$ at $273 \mathrm{~K}$. A trifluoroacetic anhydride (TFAA) solution $(13.2 \mathrm{ml}$ of a $0.8 \mathrm{M}$ solution, $10.56 \mathrm{mmol}$ ) in dry toluene was then added. The bath was removed and the solution stirred for $2 \mathrm{~h}$ at room temperature. Subsequently, the flask was immersed for $20 \mathrm{~min}$ in an oil bath preheated to 393-403 K with a reflux condenser. The solution was concentrated in a rotary evaporator and the residue was purified by flash column chromatography on silica gel, using a mixture of EtOAc/n-hexane (1:4) as the eluent. The yield of (I) was $2.103 \mathrm{~g}$ ( $80 \%$ based on TFAA). Irregular yellow crystals of (I) were obtained from the slow evaporation of its $\mathrm{CH}_{2} \mathrm{Cl}_{2}$ solution.

Spectroscopic characterization. ${ }^{1} \mathrm{H}$ NMR (300 MHz, Py- $d_{5}$, solution comprises rotamers): $\delta 8.21$ (apparent $d, J=7.3 \mathrm{~Hz}$, $2 \mathrm{H}, \mathrm{H}^{\prime}$ and $\left.\mathrm{H}^{\prime}\right), 7.54\left(d, J=8.1 \mathrm{~Hz}, 2 \mathrm{H}, \mathrm{H} 2^{\prime}\right.$ and $\left.\mathrm{H}^{\prime}\right), 6.80$ and $6.68(2 \times m, 1 \mathrm{H}, \mathrm{H} 2), 5.35\left(s, 2 \mathrm{H}, \mathrm{CH}_{2}\right), 5.03(m, 1 \mathrm{H}, \mathrm{H} 3)$, 3.71 (apparent $t, J=9.5 \mathrm{~Hz}, 2 \mathrm{H}, \mathrm{H} 5 a, 5 b), 2.46$ (apparent quint., $J=9.5 \mathrm{~Hz}, 2 \mathrm{H}, \mathrm{H} 4 a, 4 b) .{ }^{13} \mathrm{C}$ NMR $\left(75 \mathrm{MHz}, \mathrm{Py}-d_{5}\right.$, solution comprises rotamers): $\delta=152.3\left(\mathrm{CO}_{2} R\right), 151.5\left(\mathrm{CO}_{2} R\right), 147.8$ $\left(\mathrm{C}^{\prime}\right), 144.9\left(\mathrm{C}^{\prime}\right), 129.8(\mathrm{C} 2), 129.2(\mathrm{C} 2), 128.4\left(\mathrm{C}^{\prime}\right.$ and $\left.\mathrm{C}^{\prime}\right)$, $128.3\left(\mathrm{C} 2^{\prime}\right.$ and $\left.\mathrm{C}^{\prime}\right), 123.9\left(\mathrm{C}^{\prime}\right.$ and $\left.\mathrm{C}^{\prime}\right), 109.4(\mathrm{C} 3), 65.8$ $\left(\mathrm{CH}_{2}\right), 65.6\left(\mathrm{CH}_{2}\right), 45.8$ (C5), $45.4(\mathrm{C} 5), 30.1(\mathrm{C} 4), 29.0(\mathrm{C} 4)$. ESI-MS $(\mathrm{m} / z)$ calculated for $\mathrm{C}_{12} \mathrm{H}_{12} \mathrm{~N}_{2} \mathrm{O}_{4}$ 248.07971, found 248.07876 .

\section{Refinement details}

Crystal data, data collection and structure refinement details are summarized in Table 4. The carbon-bound $\mathrm{H}$ atoms were placed in calculated positions $(\mathrm{C}-\mathrm{H}=0.93-0.97 \AA)$ and were included in the refinement in the riding-model approximation, with $U_{\text {iso }}(\mathrm{H})$ set to $1.2 U_{\text {eq }}(\mathrm{C})$.

\section{Funding information}

The Brazilian agencies Coordination for the Improvement of Higher Education Personnel, CAPES and National Council for Scientific and Technological Development, CNPq, for a fellowship to JZ-S (305626/2013-2) are acknowledged for support.

\section{References}

Brandenburg, K. (2006). DIAMOND. Crystal Impact GbR, Bonn, Germany.

Bruker (2009). APEX2 and SAINT. Bruker AXS Inc., Madison, Wisconsin, USA.

Burla, M. C., Caliandro, R., Carrozzini, B., Cascarano, G. L., Cuocci, C., Giacovazzo, C., Mallamo, M., Mazzone, A. \& Polidori, G. (2015). J. Appl. Cryst. 48, 306-309.

ChemAxon (2010). Marvinsketch. http://www.chemaxon.com.

Cheng, A. Y. Y. \& Josse, R. G. (2004). Drug Discov. Today: Therapeut. Strat. 1, 201-206.
Table 4

Experimental details.

\begin{tabular}{|c|c|}
\hline \multicolumn{2}{|l|}{ Crystal data } \\
\hline Chemical formula & $\mathrm{C}_{12} \mathrm{H}_{12} \mathrm{~N}_{2} \mathrm{O}_{4}$ \\
\hline$M_{\mathrm{r}}$ & 248.24 \\
\hline Crystal system, space group & Monoclinic, $P 2_{1} / n$ \\
\hline Temperature (K) & 290 \\
\hline$a, b, c(\AA)$ & $9.0385(3), 12.2518(4), 10.5452(3)$ \\
\hline$\beta\left(^{\circ}\right)$ & $96.102(1)$ \\
\hline$V\left(\AA^{3}\right)$ & $1161.14(6)$ \\
\hline$Z$ & 4 \\
\hline Radiation type & Мo $K \alpha$ \\
\hline$\mu\left(\mathrm{mm}^{-1}\right)$ & 0.11 \\
\hline Crystal size $(\mathrm{mm})$ & $0.52 \times 0.22 \times 0.14$ \\
\hline \multicolumn{2}{|l|}{ Data collection } \\
\hline Diffractometer & Bruker APEXII CCD \\
\hline Absorption correction & $\begin{array}{l}\text { Multi-scan (SADABS; Sheldrick, } \\
\text { 1995) }\end{array}$ \\
\hline$T_{\min }, T_{\max }$ & $0.724,0.745$ \\
\hline $\begin{array}{l}\text { No. of measured, independent and } \\
\text { observed }[I>2 \sigma(I)] \text { reflections }\end{array}$ & $23727,2394,2013$ \\
\hline$R_{\text {int }}$ & 0.023 \\
\hline$(\sin \theta / \lambda)_{\max }\left(\AA^{-1}\right)$ & 0.627 \\
\hline \multicolumn{2}{|l|}{ Refinement } \\
\hline$R\left[F^{2}>2 \sigma\left(F^{2}\right)\right], w R\left(F^{2}\right), S$ & $0.041,0.117,1.09$ \\
\hline No. of reflections & 2394 \\
\hline No. of parameters & 163 \\
\hline $\mathrm{H}$-atom treatment & H-atom parameters constrained \\
\hline$\Delta \rho_{\max }, \Delta \rho_{\min }\left(\mathrm{e} \AA^{-3}\right)$ & $0.16,-0.18$ \\
\hline
\end{tabular}

Computer programs: APEX2 and SAINT (Bruker, 2009), SIR2014 (Burla et al., 2015), SHELXL2014 (Sheldrick, 2015), ORTEP-3 for Windows (Farrugia, 2012), DIAMOND (Brandenburg, 2006), MarvinSketch (ChemAxon, 2010) and publCIF (Westrip, 2010).

Farrugia, L. J. (2012). J. Appl. Cryst. 45, 849-854.

Fleet, G. W. J. \& Son, J. C. (1988). Tetrahedron, 44, 2637-2647.

Freer, A. A., McDermott, G., Melville, J. C. \& Robins, D. J. (1993). Acta Cryst. C49, 2115-2117.

Garcia, A. L. L. (2008). Ph. D. Thesis, Universidade Estadual de Campinas, UNICAMP, Campinas, SP, Brazil.

Groom, C. R., Bruno, I. J., Lightfoot, M. P. \& Ward, S. C. (2016). Acta Cryst. B72, 171-179.

Heine, H. W. \& Mente, P. G. (1971). J. Org. Chem. 36, 3076-3078.

Huang, L., Massa, L. \& Karle, J. (2008). Proc. Natl Acad. Sci. 105, 13720-13723.

Kordik, C. P. \& Reitz, A. B. (1999). J. Med. Chem. 42, 181-201.

McKinnon, J. J., Jayatilaka, D. \& Spackman, M. A. (2007). Chem. Commun. pp. 3814-3816.

Nishimura, Y. (2003). Curr. Top. Med. Chem. 3, 575-591.

Rule, C. J., Wurzburg, B. A. \& Ganem, B. (1985). Tetrahedron Lett. 26, 5379-5380.

Sheldrick, G. M. (1995). SADABS. University of Göttingen, Germany.

Sheldrick, G. M. (2015). Acta Cryst. C71, 3-8.

Taylor, S. W., Waite, J. H., Ross, M. M., Shabanowitz, J. \& Hunt, D. F. (1994). J. Am. Chem. Soc. 116, 10803-10804.

Taylor, C. M. \& Weir, C. A. (2000). J. Org. Chem. 65, 1414-1421.

Westrip, S. P. (2010). J. Appl. Cryst. 43, 920-925.

Wong, C.-H. (1997). Pure \& Appl. Chem. 69, 419-422.

Zukerman-Schpector, J., Sugiyama, F. H., Garcia, A. L. L., Correia, C. R. D., Jotani, M. M. \& Tiekink, E. R. T. (2017). Acta Cryst. E73, $1218-1222$. 


\section{supporting information}

Acta Cryst. (2018). E74, 371-375 [https://doi.org/10.1107/S2056989018002451]

\section{(4-Nitrophenyl)methyl 2,3-dihydro-1H-pyrrole-1-carboxylate: crystal structure and Hirshfeld analysis}

Julio Zukerman-Schpector, Monica Soto-Monsalve, Regina H. De Almeida Santos, Ariel L. L. Garcia, Carlos Roque D. Correia, Mukesh M. Jotani and Edward R. T. Tiekink

Computing details

Data collection: APEX2 (Bruker, 2009); cell refinement: SAINT (Bruker, 2009); data reduction: SAINT (Bruker, 2009); program(s) used to solve structure: SIR2014 (Burla et al., 2015); program(s) used to refine structure: SHELXL2014 (Sheldrick, 2015); molecular graphics: ORTEP-3 for Windows (Farrugia, 2012) and DIAMOND (Brandenburg, 2006); software used to prepare material for publication: MarvinSketch (ChemAxon, 2010) and publCIF (Westrip, 2010).

(4-Nitrophenyl)methyl 2,3-dihydro-1H-pyrrole-1-carboxylate

Crystal data

$\mathrm{C}_{12} \mathrm{H}_{12} \mathrm{~N}_{2} \mathrm{O}_{4}$

$M_{r}=248.24$

Monoclinic, $P 2_{1} / n$

$a=9.0385(3) \AA$

$b=12.2518$ (4) $\AA$

$c=10.5452(3) \AA$

$\beta=96.102(1)^{\circ}$

$V=1161.14(6) \AA^{3}$

$Z=4$

Data collection

Bruker APEXII CCD

diffractometer

$\varphi$ and $\omega$ scans

Absorption correction: multi-scan

(SADABS; Sheldrick, 1995)

$T_{\min }=0.724, T_{\max }=0.745$

23727 measured reflections

\section{Refinement}

Refinement on $F^{2}$

Least-squares matrix: full

$R\left[F^{2}>2 \sigma\left(F^{2}\right)\right]=0.041$

$w R\left(F^{2}\right)=0.117$

$S=1.09$

2394 reflections

163 parameters

0 restraints
$F(000)=520$

$D_{\mathrm{x}}=1.420 \mathrm{Mg} \mathrm{m}^{-3}$

Mo $K \alpha$ radiation, $\lambda=0.71073 \AA$

Cell parameters from 9984 reflections

$\theta=2.6-26.5^{\circ}$

$\mu=0.11 \mathrm{~mm}^{-1}$

$T=290 \mathrm{~K}$

Irregular, yellow

$0.52 \times 0.22 \times 0.14 \mathrm{~mm}$

2394 independent reflections

2013 reflections with $I>2 \sigma(I)$

$R_{\text {int }}=0.023$

$\theta_{\max }=26.5^{\circ}, \theta_{\min }=2.6^{\circ}$

$h=-9 \rightarrow 11$

$k=-15 \rightarrow 15$

$l=-13 \rightarrow 13$

Hydrogen site location: inferred from neighbouring sites

$\mathrm{H}$-atom parameters constrained

$w=1 /\left[\sigma^{2}\left(F_{\mathrm{o}}^{2}\right)+(0.0501 P)^{2}+0.3399 P\right]$

where $P=\left(F_{\mathrm{o}}^{2}+2 F_{\mathrm{c}}^{2}\right) / 3$

$(\Delta / \sigma)_{\max }<0.001$

$\Delta \rho_{\max }=0.16 \mathrm{e} \AA^{-3}$

$\Delta \rho_{\min }=-0.18 \mathrm{e} \AA^{-3}$ 


\section{Special details}

Geometry. All esds (except the esd in the dihedral angle between two 1.s. planes) are estimated using the full covariance matrix. The cell esds are taken into account individually in the estimation of esds in distances, angles and torsion angles; correlations between esds in cell parameters are only used when they are defined by crystal symmetry. An approximate (isotropic) treatment of cell esds is used for estimating esds involving l.s. planes.

Fractional atomic coordinates and isotropic or equivalent isotropic displacement parameters $\left(\AA^{2}\right)$

\begin{tabular}{lllll}
\hline & $x$ & $y$ & $z$ & $U_{\text {iso }} / U_{\text {eq }}$ \\
\hline O1 & $0.95640(13)$ & $0.32527(10)$ & $0.51064(14)$ & $0.0665(4)$ \\
O2 & $0.73098(11)$ & $0.38092(8)$ & $0.41873(11)$ & $0.0489(3)$ \\
O3 & $0.20267(15)$ & $0.75353(13)$ & $0.19648(17)$ & $0.0896(5)$ \\
O4 & $0.34938(16)$ & $0.88645(10)$ & $0.24771(15)$ & $0.0720(4)$ \\
N1 & $0.77129(13)$ & $0.20438(10)$ & $0.45899(13)$ & $0.0468(3)$ \\
N2 & $0.32222(15)$ & $0.78902(12)$ & $0.24108(13)$ & $0.0532(3)$ \\
C1 & $0.86033(17)$ & $0.10688(13)$ & $0.49447(17)$ & $0.0514(4)$ \\
H1A & 0.8888 & 0.1046 & 0.5858 & $0.062^{*}$ \\
H1B & 0.9495 & 0.1052 & 0.4508 & $0.062^{*}$ \\
C2 & $0.75720(19)$ & $0.01184(14)$ & $0.45210(19)$ & $0.0581(4)$ \\
H2A & 0.7987 & -0.0322 & 0.3881 & $0.070^{*}$ \\
H2B & 0.7401 & -0.0342 & 0.5239 & $0.070^{*}$ \\
C3 & $0.61637(18)$ & $0.06612(14)$ & $0.39787(18)$ & $0.0558(4)$ \\
H3 & 0.5308 & 0.0292 & 0.3652 & $0.067^{*}$ \\
C4 & $0.62960(16)$ & $0.17304(13)$ & $0.40258(16)$ & $0.0505(4)$ \\
H4 & 0.5549 & 0.2216 & 0.3725 & $0.061^{*}$ \\
C5 & $0.83046(16)$ & $0.30513(12)$ & $0.46670(15)$ & $0.0443(3)$ \\
C6 & $0.78181(17)$ & $0.49186(12)$ & $0.42996(17)$ & $0.0490(4)$ \\
H6A & 0.8665 & 0.5019 & 0.3819 & $0.059^{*}$ \\
H6B & 0.8127 & 0.5089 & 0.5186 & $0.059^{*}$ \\
C7 & $0.65706(15)$ & $0.56621(11)$ & $0.37923(13)$ & $0.0400(3)$ \\
C8 & $0.51427(16)$ & $0.52938(12)$ & $0.33957(14)$ & $0.0442(3)$ \\
H8 & 0.4927 & 0.4553 & 0.3436 & $0.053^{*}$ \\
C9 & $0.40373(17)$ & $0.60201(12)$ & $0.29406(15)$ & $0.0445(3)$ \\
H9 & 0.3082 & 0.5774 & 0.2672 & $0.053^{*}$ \\
C10 & $0.43818(16)$ & $0.71143(12)$ & $0.28935(13)$ & $0.0414(3)$ \\
C11 & $0.57881(17)$ & $0.75032(12)$ & $0.32932(16)$ & $0.0481(4)$ \\
H11 & 0.5996 & 0.8246 & 0.3262 & $0.058^{*}$ \\
C12 & $0.68753(17)$ & $0.67727(12)$ & $0.37385(16)$ & $0.0478(4)$ \\
H12 & 0.7828 & 0.7025 & 0.4007 & $0.057^{*}$ \\
& & & &
\end{tabular}

Atomic displacement parameters $\left(\AA^{2}\right)$

\begin{tabular}{lllllll}
\hline & $U^{11}$ & $U^{22}$ & $U^{33}$ & $U^{12}$ & $U^{13}$ & $U^{23}$ \\
\hline O1 & $0.0418(6)$ & $0.0487(7)$ & $0.1027(10)$ & $-0.0039(5)$ & $-0.0220(6)$ & $0.0065(6)$ \\
O2 & $0.0409(6)$ & $0.0331(5)$ & $0.0694(7)$ & $0.0014(4)$ & $-0.0086(5)$ & $0.0017(4)$ \\
O3 & $0.0510(8)$ & $0.0752(10)$ & $0.1334(14)$ & $0.0052(7)$ & $-0.0338(8)$ & $0.0061(9)$ \\
O4 & $0.0699(9)$ & $0.0433(7)$ & $0.0990(10)$ & $0.0135(6)$ & $-0.0083(7)$ & $0.0061(6)$ \\
N1 & $0.0352(6)$ & $0.0369(6)$ & $0.0660(8)$ & $0.0025(5)$ & $-0.0052(5)$ & $0.0040(6)$
\end{tabular}




\begin{tabular}{lllllll}
$\mathrm{N} 2$ & $0.0467(8)$ & $0.0498(8)$ & $0.0610(8)$ & $0.0086(6)$ & $-0.0039(6)$ & $0.0025(6)$ \\
$\mathrm{C} 1$ & $0.0442(8)$ & $0.0408(8)$ & $0.0681(10)$ & $0.0078(6)$ & $0.0017(7)$ & $0.0066(7)$ \\
$\mathrm{C} 2$ & $0.0561(10)$ & $0.0417(8)$ & $0.0766(11)$ & $0.0010(7)$ & $0.0070(8)$ & $0.0059(8)$ \\
$\mathrm{C} 3$ & $0.0440(8)$ & $0.0476(9)$ & $0.0752(11)$ & $-0.0077(7)$ & $0.0032(8)$ & $-0.0010(8)$ \\
$\mathrm{C} 4$ & $0.0342(8)$ & $0.0459(8)$ & $0.0696(10)$ & $-0.0006(6)$ & $-0.0026(7)$ & $0.0024(7)$ \\
$\mathrm{C} 5$ & $0.0363(7)$ & $0.0403(8)$ & $0.0545(8)$ & $0.0023(6)$ & $-0.0034(6)$ & $0.0027(6)$ \\
C6 & $0.0432(8)$ & $0.0352(7)$ & $0.0660(10)$ & $-0.0034(6)$ & $-0.0066(7)$ & $0.0011(7)$ \\
C7 & $0.0387(7)$ & $0.0369(7)$ & $0.0435(7)$ & $0.0005(6)$ & $-0.0006(6)$ & $-0.0008(6)$ \\
C8 & $0.0447(8)$ & $0.0347(7)$ & $0.0519(8)$ & $-0.0042(6)$ & $-0.0009(6)$ & $0.0008(6)$ \\
C9 & $0.0367(7)$ & $0.0434(8)$ & $0.0516(8)$ & $-0.0046(6)$ & $-0.0028(6)$ & $-0.0015(6)$ \\
C10 & $0.0391(7)$ & $0.0406(8)$ & $0.0434(7)$ & $0.0050(6)$ & $-0.0007(6)$ & $-0.0006(6)$ \\
C11 & $0.0461(8)$ & $0.0325(7)$ & $0.0640(9)$ & $-0.0023(6)$ & $-0.0019(7)$ & $-0.0013(6)$ \\
C12 & $0.0370(8)$ & $0.0392(8)$ & $0.0647(9)$ & $-0.0040(6)$ & $-0.0056(7)$ & $-0.0029(7)$ \\
& & & & & & \\
\hline
\end{tabular}

Geometric parameters $\left(\AA,{ }^{\circ}\right)$

\begin{tabular}{|c|c|c|c|}
\hline $\mathrm{O} 1-\mathrm{C} 5$ & $1.2080(18)$ & $\mathrm{C} 3-\mathrm{H} 3$ & 0.9300 \\
\hline $\mathrm{O} 2-\mathrm{C} 5$ & $1.3527(17)$ & $\mathrm{C} 4-\mathrm{H} 4$ & 0.9300 \\
\hline $\mathrm{O} 2-\mathrm{C} 6$ & $1.4356(17)$ & $\mathrm{C} 6-\mathrm{C} 7$ & $1.503(2)$ \\
\hline $\mathrm{O} 3-\mathrm{N} 2$ & $1.2123(18)$ & $\mathrm{C} 6-\mathrm{H} 6 \mathrm{~A}$ & 0.9700 \\
\hline $\mathrm{O} 4-\mathrm{N} 2$ & $1.2193(18)$ & $\mathrm{C} 6-\mathrm{H} 6 \mathrm{~B}$ & 0.9700 \\
\hline $\mathrm{N} 1-\mathrm{C} 5$ & $1.3442(19)$ & $\mathrm{C} 7-\mathrm{C} 8$ & $1.389(2)$ \\
\hline $\mathrm{N} 1-\mathrm{C} 4$ & $1.4070(18)$ & $\mathrm{C} 7-\mathrm{C} 12$ & $1.391(2)$ \\
\hline $\mathrm{N} 1-\mathrm{C} 1$ & 1.4665 (18) & $\mathrm{C} 8-\mathrm{C} 9$ & $1.385(2)$ \\
\hline $\mathrm{N} 2-\mathrm{C} 10$ & $1.4656(19)$ & $\mathrm{C} 8-\mathrm{H} 8$ & 0.9300 \\
\hline $\mathrm{C} 1-\mathrm{C} 2$ & $1.528(2)$ & $\mathrm{C} 9-\mathrm{C} 10$ & $1.378(2)$ \\
\hline $\mathrm{C} 1-\mathrm{H} 1 \mathrm{~A}$ & 0.9700 & $\mathrm{C} 9-\mathrm{H} 9$ & 0.9300 \\
\hline $\mathrm{C} 1-\mathrm{H} 1 \mathrm{~B}$ & 0.9700 & $\mathrm{C} 10-\mathrm{C} 11$ & $1.381(2)$ \\
\hline $\mathrm{C} 2-\mathrm{C} 3$ & $1.495(2)$ & $\mathrm{C} 11-\mathrm{C} 12$ & $1.374(2)$ \\
\hline $\mathrm{C} 2-\mathrm{H} 2 \mathrm{~A}$ & 0.9700 & $\mathrm{C} 11-\mathrm{H} 11$ & 0.9300 \\
\hline $\mathrm{C} 2-\mathrm{H} 2 \mathrm{~B}$ & 0.9700 & $\mathrm{C} 12-\mathrm{H} 12$ & 0.9300 \\
\hline $\mathrm{C} 3-\mathrm{C} 4$ & $1.316(2)$ & & \\
\hline $\mathrm{C} 5-\mathrm{O} 2-\mathrm{C} 6$ & $115.15(11)$ & $\mathrm{O} 1-\mathrm{C} 5-\mathrm{O} 2$ & $124.40(14)$ \\
\hline $\mathrm{C} 5-\mathrm{N} 1-\mathrm{C} 4$ & $127.92(13)$ & $\mathrm{N} 1-\mathrm{C} 5-\mathrm{O} 2$ & $111.31(12)$ \\
\hline $\mathrm{C} 5-\mathrm{N} 1-\mathrm{C} 1$ & $121.91(12)$ & $\mathrm{O} 2-\mathrm{C} 6-\mathrm{C} 7$ & $108.85(12)$ \\
\hline $\mathrm{C} 4-\mathrm{N} 1-\mathrm{C} 1$ & $109.61(12)$ & $\mathrm{O} 2-\mathrm{C} 6-\mathrm{H} 6 \mathrm{~A}$ & 109.9 \\
\hline $\mathrm{O} 3-\mathrm{N} 2-\mathrm{O} 4$ & $122.62(15)$ & $\mathrm{C} 7-\mathrm{C} 6-\mathrm{H} 6 \mathrm{~A}$ & 109.9 \\
\hline $\mathrm{O} 3-\mathrm{N} 2-\mathrm{C} 10$ & $118.50(14)$ & $\mathrm{O} 2-\mathrm{C} 6-\mathrm{H} 6 \mathrm{~B}$ & 109.9 \\
\hline $\mathrm{O} 4-\mathrm{N} 2-\mathrm{C} 10$ & $118.88(14)$ & $\mathrm{C} 7-\mathrm{C} 6-\mathrm{H} 6 \mathrm{~B}$ & 109.9 \\
\hline $\mathrm{N} 1-\mathrm{C} 1-\mathrm{C} 2$ & $104.18(12)$ & $\mathrm{H} 6 \mathrm{~A}-\mathrm{C} 6-\mathrm{H} 6 \mathrm{~B}$ & 108.3 \\
\hline $\mathrm{N} 1-\mathrm{C} 1-\mathrm{H} 1 \mathrm{~A}$ & 110.9 & $\mathrm{C} 8-\mathrm{C} 7-\mathrm{C} 12$ & $119.16(13)$ \\
\hline $\mathrm{C} 2-\mathrm{C} 1-\mathrm{H} 1 \mathrm{~A}$ & 110.9 & $\mathrm{C} 8-\mathrm{C} 7-\mathrm{C} 6$ & $123.24(13)$ \\
\hline $\mathrm{N} 1-\mathrm{C} 1-\mathrm{H} 1 \mathrm{~B}$ & 110.9 & $\mathrm{C} 12-\mathrm{C} 7-\mathrm{C} 6$ & $117.59(12)$ \\
\hline $\mathrm{C} 2-\mathrm{C} 1-\mathrm{H} 1 \mathrm{~B}$ & 110.9 & $\mathrm{C} 9-\mathrm{C} 8-\mathrm{C} 7$ & $120.57(14)$ \\
\hline $\mathrm{H} 1 \mathrm{~A}-\mathrm{C} 1-\mathrm{H} 1 \mathrm{~B}$ & 108.9 & $\mathrm{C} 9-\mathrm{C} 8-\mathrm{H} 8$ & 119.7 \\
\hline $\mathrm{C} 3-\mathrm{C} 2-\mathrm{C} 1$ & $103.94(13)$ & $\mathrm{C} 7-\mathrm{C} 8-\mathrm{H} 8$ & 119.7 \\
\hline $\mathrm{C} 3-\mathrm{C} 2-\mathrm{H} 2 \mathrm{~A}$ & 111.0 & $\mathrm{C} 10-\mathrm{C} 9-\mathrm{C} 8$ & $118.68(13)$ \\
\hline
\end{tabular}




$\begin{array}{llll}\mathrm{C} 1-\mathrm{C} 2-\mathrm{H} 2 \mathrm{~A} & 111.0 & \mathrm{C} 10-\mathrm{C} 9-\mathrm{H} 9 & 120.7 \\ \mathrm{C} 3-\mathrm{C} 2-\mathrm{H} 2 \mathrm{~B} & 111.0 & \mathrm{C} 8-\mathrm{C} 9-\mathrm{H} 9 & 120.7 \\ \mathrm{C} 1-\mathrm{C} 2-\mathrm{H} 2 \mathrm{~B} & 111.0 & \mathrm{C} 9-\mathrm{C} 10-\mathrm{C} 11 & 121.93(14) \\ \mathrm{H} 2 \mathrm{~A}-\mathrm{C} 2-\mathrm{H} 2 \mathrm{~B} & 109.0 & \mathrm{C} 9-\mathrm{C} 10-\mathrm{N} 2 & 119.17(13) \\ \mathrm{C} 4-\mathrm{C} 3-\mathrm{C} 2 & 110.99(14) & \mathrm{C} 11-\mathrm{C} 10-\mathrm{N} 2 & 118.90(13) \\ \mathrm{C} 4-\mathrm{C} 3-\mathrm{H} 3 & 124.5 & \mathrm{C} 12-\mathrm{C} 11-\mathrm{C} 10 & 120.6 \\ \mathrm{C} 2-\mathrm{C} 3-\mathrm{H} 3 & 124.5 & \mathrm{C} 12-\mathrm{C} 11-\mathrm{H} 11 & 120.6 \\ \mathrm{C} 3-\mathrm{C} 4-\mathrm{N} 1 & 111.26(14) & \mathrm{C} 10-\mathrm{C} 11-\mathrm{H} 11 & 120.90(13) \\ \mathrm{C} 3-\mathrm{C} 4-\mathrm{H} 4 & 124.4 & \mathrm{C} 11-\mathrm{C} 12-\mathrm{C} 7 & 119.5 \\ \mathrm{~N} 1-\mathrm{C} 4-\mathrm{H} 4 & 124.4 & \mathrm{C} 11-\mathrm{C} 12-\mathrm{H} 12 & 119.5 \\ \mathrm{O} 1-\mathrm{C} 5-\mathrm{N} 1 & 124.29(13) & \mathrm{C} 7-\mathrm{C} 12-\mathrm{H} 12 & -175.74(14) \\ & & & 0.6(2) \\ \mathrm{C} 5-\mathrm{N} 1-\mathrm{C} 1-\mathrm{C} 2 & -171.59(15) & \mathrm{O} 2-\mathrm{C} 6-\mathrm{C} 7-\mathrm{C} 12 & 179.78(14) \\ \mathrm{C} 4-\mathrm{N} 1-\mathrm{C} 1-\mathrm{C} 2 & 0.51(18) & \mathrm{C} 12-\mathrm{C} 7-\mathrm{C} 8-\mathrm{C} 9 & -0.2(2) \\ \mathrm{N} 1-\mathrm{C} 1-\mathrm{C} 2-\mathrm{C} 3 & -0.98(18) & \mathrm{C} 6-\mathrm{C} 7-\mathrm{C} 8-\mathrm{C} 9 & -0.4(2) \\ \mathrm{C} 1-\mathrm{C} 2-\mathrm{C} 3-\mathrm{C} 4 & 1.2(2) & \mathrm{C} 7-\mathrm{C} 8-\mathrm{C} 9-\mathrm{C} 10 & 179.85(13) \\ \mathrm{C} 2-\mathrm{C} 3-\mathrm{C} 4-\mathrm{N} 1 & -0.9(2) & \mathrm{C} 8-\mathrm{C} 9-\mathrm{C} 10-\mathrm{C} 11 & -6.2(2) \\ \mathrm{C} 5-\mathrm{N} 1-\mathrm{C} 4-\mathrm{C} 3 & 171.74(16) & \mathrm{C} 8-\mathrm{C} 9-\mathrm{C} 10-\mathrm{N} 2 & 173.50(15) \\ \mathrm{C} 1-\mathrm{N} 1-\mathrm{C} 4-\mathrm{C} 3 & 0.2(2) & \mathrm{O} 3-\mathrm{N} 2-\mathrm{C} 10-\mathrm{C} 9 & 174.03(17) \\ \mathrm{C} 4-\mathrm{N} 1-\mathrm{C} 5-\mathrm{O} 1 & -175.78(17) & \mathrm{O} 4-\mathrm{N} 2-\mathrm{C} 10-\mathrm{C} 9 & -6.2(2) \\ \mathrm{C} 1-\mathrm{N} 1-\mathrm{C} 5-\mathrm{O} 1 & -5.2(3) & \mathrm{O} 3-\mathrm{N} 2-\mathrm{C} 10-\mathrm{C} 11 & 0.6(2) \\ \mathrm{C} 4-\mathrm{N} 1-\mathrm{C} 5-\mathrm{O} 2 & 4.1(2) & \mathrm{O} 4-\mathrm{N} 2-\mathrm{C} 10-\mathrm{C} 11 & -179.62(14) \\ \mathrm{C} 1-\mathrm{N} 1-\mathrm{C} 5-\mathrm{O} 2 & 174.65(14) & \mathrm{C} 9-\mathrm{C} 10-\mathrm{C} 11-\mathrm{C} 12 & -0.2(2) \\ \mathrm{C} 6-\mathrm{O} 2-\mathrm{C} 5-\mathrm{O} 1 & -3.7(2) & \mathrm{N} 2-\mathrm{C} 10-\mathrm{C} 11-\mathrm{C} 12 & -179.60(15) \\ \mathrm{C} 6-\mathrm{O} 2-\mathrm{C} 5-\mathrm{N} 1 & 176.46(13) & \mathrm{C} 10-\mathrm{C} 11-\mathrm{C} 12-\mathrm{C} 7 & \\ \mathrm{C} 5-\mathrm{O} 2-\mathrm{C} 6-\mathrm{C} 7 & -176.99(13) & \mathrm{C} 8-\mathrm{C} 7-\mathrm{C} 12-\mathrm{C} 11 & \mathrm{C} 12) \\ \mathrm{O} 2-\mathrm{C} 6-\mathrm{C} 7-\mathrm{C} 8 & 5.1(2) & \mathrm{C} 6-\mathrm{C} 7-\mathrm{C} 12-\mathrm{C} 11 & \\ & & & \end{array}$

Hydrogen-bond geometry $\left(A,{ }^{\circ}\right)$

$\mathrm{Cg} 1$ is the centroid of the $\mathrm{N} 1 / \mathrm{C} 1-\mathrm{C} 4$ ring.

\begin{tabular}{lllll}
\hline$D-\mathrm{H} \cdots A$ & $D-\mathrm{H}$ & $\mathrm{H} \cdots A$ & $D \cdots A$ & $D-\mathrm{H} \cdots A$ \\
\hline $\mathrm{C} 4-\mathrm{H} 4 \cdots \mathrm{O} 3^{\mathrm{i}}$ & 0.93 & 2.40 & $3.227(2)$ & 149 \\
$\mathrm{C} 12-\mathrm{H} 12 \cdots \mathrm{O} 1^{\mathrm{ii}}$ & 0.93 & 2.47 & $3.318(2)$ & 152 \\
$\mathrm{~N} 2-\mathrm{O} 4 \cdots C g 1^{\mathrm{iii}}$ & $1.22(1)$ & $3.42(1)$ & $3.6327(16)$ & $90(1)$
\end{tabular}

Symmetry codes: (i) $-x+1 / 2, y-1 / 2,-z+1 / 2$; (ii) $-x+2,-y+1,-z+1$; (iii) $-x+1,-y+1,-z+1$. 